\title{
Utilization of Delignified Sawdust as Raw Material of Biogas Production
}

\author{
Asfarina Zumalla $^{1 *}$, Budiyono ${ }^{2}$, Siswo Sumardiono ${ }^{2}$ \\ ${ }^{1}$ Master Degree of Department of Chemical Engineering, Faculty of Engineering, Diponegoro University, J1. Prof. Sudarto, Tembalang- \\ Semarang, 50275, Telp/fax: (024)7460058 / (024)76480675 \\ ${ }^{2}$ Department of Chemical Engineering, Faculty of Engineering, Diponegoro University ,Jl. Prof. Sudarto, Tembalang-Semarang, 50275, \\ Telp/fax: (024)7460058 / (024)76480675
}

\begin{abstract}
Biogas is one alternative to replace the irreplaceable energy source that has begun to diminish its existence. The raw materials for biogas manufacture are renewable biomass, usually using plantation waste, agriculture, and livestock. Using biogas can also reduce environmental pollution. One of the agricultural waste that has great potential to become the raw material of biogas is teak sawdust. Wood processing industry in Indonesia quite a lot, but wood has a high lignosesluosa content, so it needs the right method to process it. With the delignification of lignin levels on teak sawdust will decrease. Wood sawdust is soaked using $\mathrm{NaOH}$ for $1,2,3$, and 4 days with $4 \% \mathrm{w} / \mathrm{v}$ concentration. The lowest lignin and hemicellulose content was $25.79 \%$ and $87.9 \%$ in pretreatment for 4 days, while the highest cellulose level was $57,34 \%$. The accumulated volume of biogas at 1 day pretreatment, ie $709 \mathrm{ml} / \mathrm{g}$ TS. Gcms shows the enlarged peak area of methanamine, N-methyl from before pretreatment. The fastest biogas formation $(\lambda)$ in 4 days pretreatment, 1.60403 days and the largest constant A and U variables at 1 day were $914.5903 \mathrm{ml} / \mathrm{g}$ TS and $34.59765 \mathrm{ml} /$ g TS.
\end{abstract}

\section{Introduction}

Raw materials with lignocellulosic content are known as potential raw materials to produce environmentally friendly alternative fuels. The timber industry is an industry that produces many lignocellulosic wastes, since wood is a high-lithocellulose raw material [1]. Wood saw waste in Indonesia has not been utilized optimally, causing environmental pollution [2]. Utilizing waste wood industry in Indonesia, is a great potential to become alternative energy raw materials.

Diversification of energy is one way to be able to deal with the scarcity of oil resources and to reduce environmental pollution. Utilization of biogas as an alternative energy is possible to be applied in Indonesia because it has a potential of 49,807.43 MW derived from the activities of forest processing industry, agriculture, plantation, and sewage waste[3]. Biogas is one of the renewable alternative sources of energy that has the potential to replace fossil energy sources[4-6]. Biogas processing using anaerobic digestion process, with methane content $\left(\mathrm{CH}_{4}\right)$ is $55-70 \%$, carbon dioxide $\left(\mathrm{CO}_{2}\right)$ of $34-45 \%$, and other gas with small quantities are $\mathrm{CO}, \mathrm{N}_{2}, \mathrm{H}_{2}, \mathrm{H}_{2} \mathrm{~S}, \mathrm{O}_{2}$ [7-9].

The process of Anaerobic Digestion (AD) is the process of transforming organic waste into biogas using microbacteria through conditions without oxygen [10]. There are 4 main processes in the process of Anaerobic Digestion, that are hydrolysis, acidogenesis, acetogenesis, and methanogenesis [11].
Hydrolysis process is the process of changing organic polymer material into monomer. Fat is hydrolyzed into fatty acids or glycerol, the protein is hydrolyzed to asama amino or peptide, and carbohydrates are hydrolyzed into monosaccharides and disaccharides [12]. The process of acidogenesis is the process of forming the result of hydrolysis into organic acid by acid-forming bacteria. The organic acids formed are acetic acid, propionic acid, butyric acid, and valeric acid [13]. The process of Acetogenesis converts organic acids which are oxidized to acetic acid and hydrogen by acetogenic bacteria [14].The process of methanogenesis is the process of converting acetic acid to carbon dioxide and methane by acetropic organisms and by reducing carbon dioxide with hydrogen by hydrogenotropic organisms. The dominant methanogens used in biogas reactors are Methanobacterium, Methanothermobacter, Methanobrevibacter, Methanosarcina and Methanosaeta [12].

Based on its Total Solid (TS) content, the Anaerobic Digestion process is divided into two types: Liquid AD (L-AD) and Solid State AD (SS-AD) [15]. Liquid Anaerobic Digestion (L-AD) is an anaerobic digestion process having a total solid strength (TS) of less than $15 \%$, usually L-AD source from food waste, fertilizer, or animal waste [16]. Solid State Anaerobic Digestion (SS-AD) has a raw material having a total

\footnotetext{
* Corresponding author: asfarina.zumalla@yahoo.com
} 
solid content (TS) of more than 15\% [17]. SS-AD is considered more advantageous than L-AD, because it requires smaller reactor volumes, less energy required for heating, easier handling of raw materials, and less energy loss to be more efficient [18].

The problem for raw materials that have a high TS is to have a high enough lignocellulosic content. Lignocellulose makes the raw material difficult to be processed into biogas, so the need for action to reduce the content of lignocellulose in raw materials to be used [19]. Lignocellulose consists of three main components, namely cellulose, hemerusulose, and lignin. They form a complex chemical bond into the base material of the plant cell wall [20].

Cellulose is the main component of the cell wall. Cellulose is a glucose polymer with $\beta-1,4$-glucoside bonds in a straight chain. Build a cellulose base in the form of a selobiose that is a dimer of glucose. The long chain of cellulose is connected together through the hydrogen bonds and van der waals forces. Cellulose molecules are microfibrils of glucose bound to one another forming a very long polymer chain. Cellulose is a polysaccharide consisting of units and has a relatively high molecular mass, composed of 2,0003,000 glucose. The cellulose molecule formula is $\left(\mathrm{C}_{6} \mathrm{H}_{10} \mathrm{O}_{5}\right) \mathrm{n}$. Cellulose is a major component of the plant cell wall wall that is glucose polymer composed of $\beta$-1,4-glucose units connected with $\beta-1,4$ Dllycoside bond. The bonds of $\beta-1,4$ glucoside in cellulose fibers can be broken down into glucose monomers by acid or enzymatic hydrolysis. A perfect cellulose hydrolysis will produce a cellulose monomer called glucose. The presence of lignin and hemicellulose around the cellulose is a major obstacle to hydrolyzing cellulose [21-22].

The hemicellulose chain is shorter than the cellulose chain, due to the lower degree of polymerization. In contrast to cellulose, the hemicellulosic polymer is not straight but is a branched polymer and its structure is not crystalline. The hemicellulosic sugar monomer comprises a five-carbon (pentose / C-6), hexuronic and hexose deoxy carbonated monomer. Hemicellulose will undergo oxidation and degradation reactions first than cellulose, due to its shorter and branched chain of molecules. Hemicellulose is hydrophilic (easy to absorb water) resulting in a less orderly structure. Structurally, hemicellulose is similar to cellulose which is a sugar polymer [21-22].

Lignin is one component of the plant. Lignin is a complex molecule composed of phenylphropane units bound in three-dimensional structures, Lignin is very resistant to degradation, either biologically, enzymatically or chemically. Lignin is a threedimensional polymer comprising a propane phenyl unit through an ete bond (C-O-C) and a carbon bond (C-C) [21-22].

High content of Lignocellulose in biomass causes biomass is difficult to be processed into biogas, so the need for pretreatement. The usual types of pretreatment are pretreatment chemically, physics and biology [23]. Alkali pretreatment is an effective pretreatment method for dissolving lignin and also can neutralize a variety of acidic products from lignocellulosic complex [2425]. Using $\mathrm{NaOH}$ for the delignification process because this solution can damage the lignin structure of the crystalline and amorphous parts, and separate some of the hemicellulose. Hemicellulose has an amorphous structure so that the use of $\mathrm{NaOH}$ can remove lignin sekgus extracting hemicellulose. Thus it causes the pretreatment to use alkali more effectively than other prerations [26].

The $\mathrm{OH}$-ions of $\mathrm{NaOH}$ will break the bonds from the ligmin base structure, while the $\mathrm{Na}+$ will bind to lignin to form sodium phenolate. This phenolic salt is soluble. Dissolved lignin is characterized by black in a solution called black liquor. After the immersion process, the sample is filtered to remove the dissolved lignin in the solution and then the sample is washed with water to clean the solution still attached to the sample [27].

\section{Experimental Method}

\subsection{Materials}

This Biogas using raw material from sawdust, that produced from home industry from Central Java, Indonesia. The rumen obtained from RPH Ungaran. $\mathrm{NaOH}$ of $4 \% \mathrm{w} / \mathrm{v}$ used for pretreatment. $\mathrm{HCl}$ of $0.2 \mathrm{~N}$ is used to neutralize ph.

Tabel 1. Sawdust and rumen properties used as biogas feedstock

\begin{tabular}{ccc}
\hline Parameter & Sawdust & Rumen \\
\hline TS (\%) & 88,5 & 19,88 \\
VS(\%) & 86 & 12,46 \\
C (\%) & 30,9 & 10 \\
N(\%) & 0,35 & 0,56 \\
Rasio C/N & 88,3 & 17,86 \\
\hline
\end{tabular}

\subsection{Delignification Process}

Sodium hydroxide $(\mathrm{NaOH})$ with $4 \%$ w / v concentration is used for the sawdust delignification process. The process is done at room temperature during $(1,2,3,4$ day) with liquid to solid ratio that is $100 \mathrm{ml}$ liquid per five gram sawdust. After the delignification process, sawdust is washed with aquades and $\mathrm{HCl} 0,2 \mathrm{~N}$, then dried in an oven at a temperature of $100^{\circ} \mathrm{C}$ to a constant weight.

\subsection{Anaerobic Digestion Process.}

Total Solid (TS) required for making this biogas is $20 \%$. The digester has a volume of $1 \mathrm{~L}$. The biogas made has an initial ph 7 , because the methanogenic bacteria can work well on ph 6.6-7.6 and it is the best ph for microbial growth. The composition of $\mathrm{C} / \mathrm{N}$ has a 30/1 ratio, because of the best composition for microbial nutrition in order to develop maximally. Then put in the rumen, water, urea and sample. The digester bottle must be sealed, until no air enters the digester bottle. After that, observed the anaerobic 
digestion process until 30 days. The product of Anaerobic Digestion analyzed by Gas Chromatography - Mass Spectrometry. The kinetics of gas volume is calculated by Goempertz equation.

\section{Result And Discussion}

\subsection{Results and Discussion Effect of Duration Soaking with $\mathrm{NaOH}$ to the content of Lignocellulose}

Effect of soaking time on the content of the lignocellulosic $\mathrm{NaOH}$ in the sawdust have long immersion variations are $0,1,2,3$ and 4 days with $\mathrm{NaOH}$ concentration of $4 \% \mathrm{w} / \mathrm{v}$. The analysis was conducted to determine the content of lignocellulose on sawdust using Chesson analysis [28]. Chesson analysis results can be seen in Figure 1, Figure 2 and Figure 3.

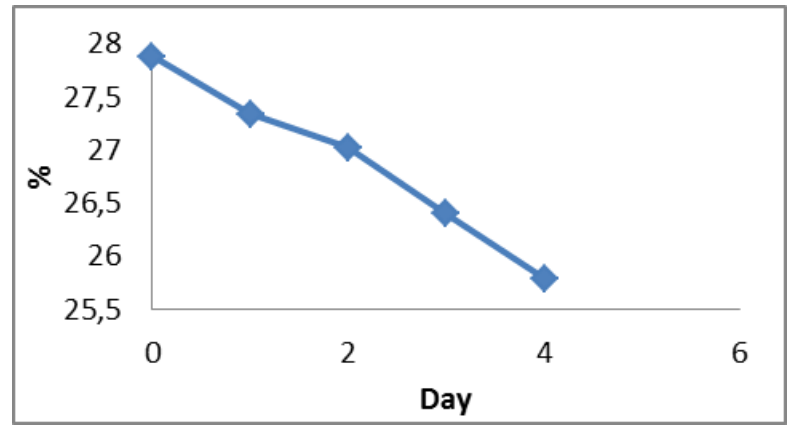

Fig. 1. Lignin on Sawdust For $0,1,2,3$, and 4 days pretreatment

Figure 1 can be seen that there is a decrease in the content of lignin every day on sawdust sawdust that has been soaked for $0,1,2,3$, and 4 days. The content of lignin at 0 days has $27,88 \%$, the immersion of 1 day have the level 27,34\%, 2 day have the content $27,02 \%$, 3 day have the content $26,4 \%$, and 4 day have the content $25,79 \%$ From the analysis that has been done the results obtained is 4 days of immersion has the least content, there is $25.79 \%$.

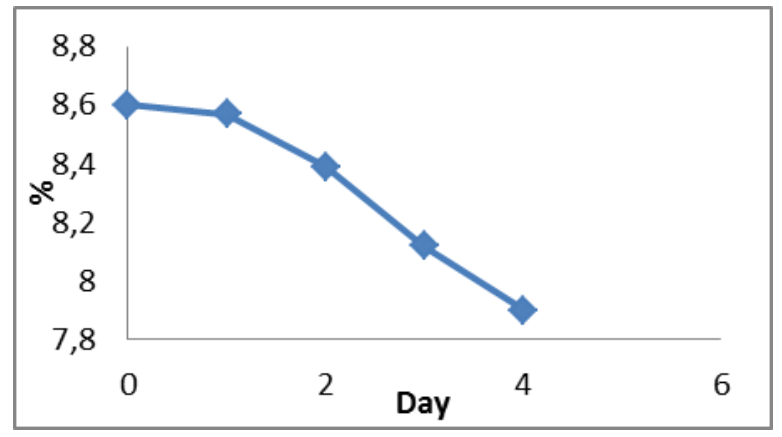

Fig. 2. Hemicellulose on Sawdust for $0,1,2,3$ and 4 days pretreatment

Figure 2 shown the hemicellulose content of sawdust that immersed by $\mathrm{NaOH} 4 \% \mathrm{w} / \mathrm{v}$ at $0,1,2,3$, and 4 days. In day 0 immersion, sawdust has $8.6 \%$, on day 1 has $8,57 \%$, day 2 has $8,39 \%$, day 3 has $8,12 \%$, and day 4 has a level of $7.9 \%$. From the graph above, it can be seen that the longer immersion hemicellulose levels decreased. Hemicellulose levels were at least 4 days, that is $7.9 \%$.

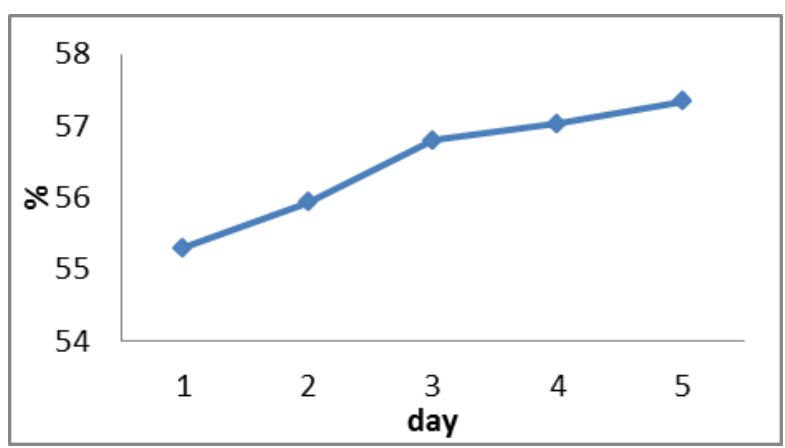

Fig. 3. Cellulose on Sawdust for $0,1,2,3$ and 4 days pretreatment

Cellulose content can be seen from Figure 3, an increase from day 0 to day 4 . On day 0 concentration of cellulose was $55.3 \%$, and then on day 1 of cellulose content of $55.93 \%$, a day to two levels of cellulose 56 , $8 \%$, day 3 level $57.03 \%$, and the highest is cellulose level on day 4 , that is $57,34 \%$. This phenomenon occurs due to the occurrence of hemicellulose degradation into xylose, arabinose and glucose [29]. Cellulose can be converted to glucose, and hemicellulose to xylose, arabinose, galactose and glucose [20].

The phenomenon of Figures 1 and 2 decreases the percentage of lignin and hemicellulose content each day in teak sawdust. This decrease is due to the initial treatment of $\mathrm{NaOH}$ which can change the chemical composition, chemical structure, and physical characteristics of sawdust during pretreatment, thus increasing the biodegradability of teak sawdust [30]. The content of lignin before immersion using $\mathrm{NaOH}$ was $27.88 \%$, then after immersion to $25.79 \%$. Like lignin, hemicellulose also decreased $8.6 \%$ before immersion and $7.9 \%$ after immersion. This decrease means the conversion of insoluble fiber to soluble component, besides pretreatment of sawdust saw using $\mathrm{NaOH}$ causes delignification by breaking the ester bond on lignin and hemicellulose, and increasing porosity of biomass [31].

\subsection{Effect of Immersion with $\mathrm{NaOH} 4 \%$ w/v on Biogas Volume}

After soaking the teak sawdust with $\mathrm{NaOH} 4 \%$ w / v for $0,1,2,3$, and 4 days, the sawdust is used for raw material from biogas manufacture. The biogas made has an initial ph 7, because the methanogenic bacteria can work well on ph 6.6-7.6 because it is the best ph for microbial growth [6]. The $\mathrm{C} / \mathrm{N}$ composition has a $30 / 1$ ratio because of the best composition for microbial nutrients to develop maximally [32]. The effect of sawdust immersion using $\mathrm{NaOH} 4 \% \mathrm{w} / \mathrm{v}$ was observed with variations of immersion duration. 


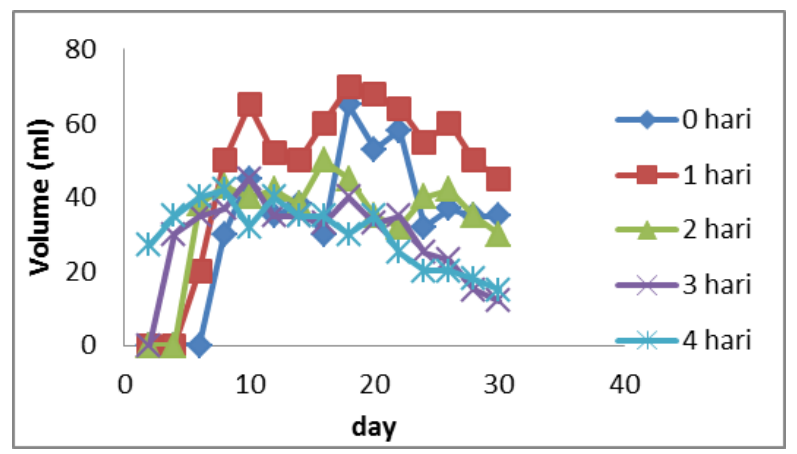

Fig. 4. Biogas Volume Measurement Results

Based on FIG. 4, the first biogas formed is to immerse for 4 days at a volume of $27 \mathrm{ml} / \mathrm{g}$ TS. On day 4 , biogas begins to form for immersion variables for 3 days with volume $30 \mathrm{ml} / \mathrm{g}$ TS. On day 6 , biogas begins to form for immersion variables for 2 days and 1 day with consecutive volume of $38 \mathrm{ml} / \mathrm{g}$ TS and 20 $\mathrm{ml} / \mathrm{g}$ TS. On day 8, biogas begins to form for variables without immersion with a volume of $30 \mathrm{ml} /$ g TS.

The phenomenon in Figure 4 is due to the number of lignin in each variable. Chesson analysis conducted before making biogas fermentation to get the result of reduced lignin content the longer done soaking of sawdust teak. The lowest lignin level on pretreatment for 4 days of immersion using $4 \% \mathrm{w} / \mathrm{v} \mathrm{NaOH}$, ie $25.79 \%$. Before pretreatment using $\mathrm{NaOH}$, the lignin content was 27.88 The phenomenon affects the process of the formation of sawdust teak into biogas. Variables without immersion are the longest-producing variables of biogas, because they have high lignin levels, so the fermentation process of biogas formation is quite hampered by the presence of high lignin [33]. Lignin that lies between the cells and inside the cell wall serves as a glue to bond between cells, which can lead to limited rate and extension of hydrolysis, since lignin is protective and complicates digestion of substrate by microbes. Substrate that is difficult to digest by microbes leads to the longer formation of biogas in the fermentation process, so before pretreatment using $\mathrm{NaOH}$ there is longer gas formation compared with the dipretreatment sawdust [29]. The most rapid variable produces biogas is 4 days immersion variable, which starts to form after 2 days of fermentation in the digester. The formation of biogas faster than other variables is due to more dissolved and fragmented lignin compared with pretreatment for 1 day, 2 days, and 3 days. Low levels of lignin is evidenced by the chesson analysis that obtained the lowest results on 4 days of immersion using $\mathrm{NaOH} 4 \% \mathrm{w} / \mathrm{v}$, ie $25.79 \%$. Low levels of lignin will cause reduced and loosened lignin bonds of cellulose and hemicellulose [34]. Reduced and loosened lignin bonds will accelerate the process of cellulose hydrolysis in sawdust to biogas in fermentation, so the formation of biogas at soaking 4 days faster than immersion for 1 day, 2 days, and 3 days [35].

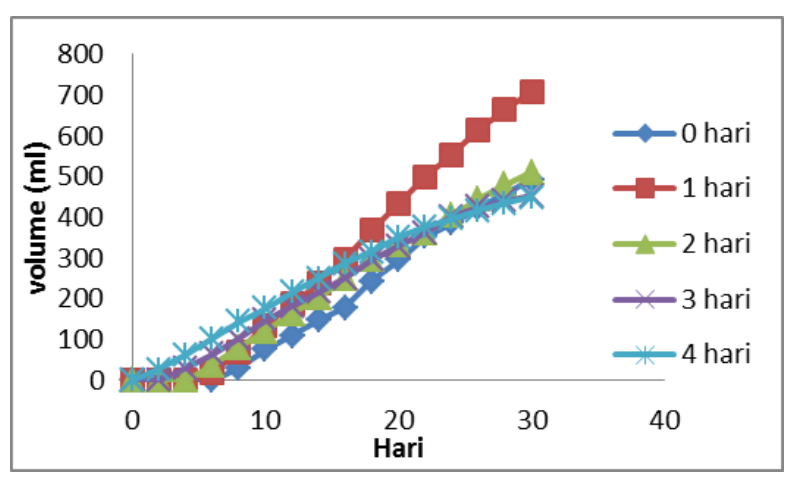

Fig. 5. Accumulation of Biogas Production

Figure 5 shows that the highest cumulative biogas volume is found in 1 day immersion variables with biogas volume reaching $709 \mathrm{ml} / \mathrm{g}$ TS. For the 0 days immersion variable, the biogas volume reached $493 \mathrm{ml}$ / g TS. The 2-day immersion variable reaches $510 \mathrm{ml} /$ $\mathrm{g}$ TS, 3 days of immersion of $452 \mathrm{ml} / \mathrm{g}$ TS and the least is for 4 days of immersion with volume of $449 \mathrm{ml}$ / g TS.

The increase in biogas volume from before pretreatment and after pretreatment for 1 day, due to reduced lignin level before pretreatment. In the chesson analysis obtained lignin levels are reduced from before soaking, ie $27.34 \%$. Reduced lignin levels are caused by the destruction of ester bonds in the LCC (Lignin Carbohydrate Complex) by hydrolysis reaction, so the bonds between units and lignin functional groups, cellulose, and hemicellulose are damaged causing chemical structure changes. Changes in chemical composition, chemical structure, and physical characteristics lead to the easy process of degradation into biogas. Increased cellulose levels can also increase the volume of biogas in pretreatment for 1 day. This phenomenon causes the volume to be formed on immersion for 1 day [36].

Day 2 until day 4 there was a decrease in the accumulation of biogas volume, ie day 2 had accumulated $510 \mathrm{ml} / \mathrm{g}$ TS less than 1 day immersion of $709 \mathrm{ml} / \mathrm{g}$ TS. The phenomenon is inversely related to the phenomenon of chesson analysis which shows the longer the immersion the less lignin content, should the accumulation of biogas volume increase. The results obtained on the fermentation of sawdust sawdust using $4 \% \mathrm{w} / \mathrm{v} \mathrm{NaOH}$ indicated that soaking for 2 days, 3 days and 4 days was getting fewer results than immersion for 1 day. The decrease is due to the more $\mathrm{NaOH}$ absorbed in the raw material will cause anaerobic microbial inhibition due to high $\mathrm{Na}+$ concentration and the effect on the lignin decomposer [37-38]. Utilization of $\mathrm{NaOH}$ pretreatment may cause inhibition of $\mathrm{Na}+$ ions in methanogenesis [39]. This phenomenon resulted in the accumulation of biogas volume at 2 days, 3 days and 4 days less than 1 day immersion, although in the biogas formation process the fastest occurred in 4 days immersion variable due to low lignin and hemicellulose levels. 


\subsection{The Influence of Immersion on Biogas Content Characteristics}

After immersion and biogas preparation, further analysis is needed to determine the changes of the biogas composition formed after and before immersion.

Table 2. Area and Biogas Component Area Before Immersion

\begin{tabular}{ll}
\hline Area & Name \\
\hline 4297054 & Methanamine, N-methyl- (CAS) \\
15257372 & Methanamine, N-methyl- (CAS) \\
\hline
\end{tabular}

Table 2 shows the differences in the area of components found in teak sawdust. The area before immersion $\mathrm{NaOH} 4 \% \mathrm{w} / \mathrm{v}$ is 4,297,054, whereas after immersion $\mathrm{NaOH} 4 \% \mathrm{w} / \mathrm{v}$ is $15,257,372$. The greater area of the peak area after pretreatment shows that more methanamine N-methyl composition in biogas after pretreatment. The phenomenon is caused by damage to lignin and hemicellulose and the occurrence of de-esterification (saponification) in the bonds of intermolecules ester [31]. It also changes the degree of polymerization of each component, altering the physical characteristics of teak sawdust, ie changes in surface area, porosity, and crystallinity [40], altering chemical composition, and chemical structure [30]. Pretreatment using $\mathrm{NaOH}$ causes decreased lignin and hemicellulose content in teak sawdust, thus increasing biodegradability and increased biogas production [36].

\subsection{Effect of Immersion with $\mathrm{NaOH}$ on Biogas Formation Rate}

Biogas production data obtained from the study were matched with the modified Goempertz equation (Equation 1) [41]. In the modified Goempertz equation it assumes the cumulative biogas production in batch digesters is in line with the bacterial growth rate [4248]. The modified Goempertz equation is as follows:

$$
y(t)=A \cdot \exp \left\{-\exp \left[\frac{\mu \cdot \theta}{A}(\lambda-t)+1\right]\right\}
$$

Where $\mathrm{P}$ is the production of cumulative biogas $(\mathrm{ml}), \mathrm{A}$ is the production of potential cumulative biogas ( $\mathrm{ml} / \mathrm{g} \mathrm{TS}), \mathrm{U}$ is the maximum biogas production rate ( $\mathrm{ml} / \mathrm{g}$ TS days), e is the mathematical constant of $2.71828, \lambda$ is the adaptation time bacteria (minimum start time of cumulative biogas production is calculated (days). The constants $\mathrm{A}, \mathrm{U}$, and $\lambda$ can be determined by using nonlinear regression with the help of POLYMATH software [43-48].
Table 3. Kinetic Constant of Biogas Production

\begin{tabular}{lllll}
\hline Variabel & $\begin{array}{l}\mathrm{A} \\
(\mathrm{ml} / \mathrm{g}\end{array}$ & $\begin{array}{l}\mathrm{U} \\
\text { (ml/gr } \\
\text { TS })\end{array}$ & $\lambda($ hari $)$ & $\mathrm{R}^{2}$ \\
& TShi) & & \\
\hline 0 day & 621,5533 & 25,88708 & 8,52624 & 0,99789 \\
& & & 8 & 3 \\
1 day & 914,5903 & 34,59765 & 7,29931 & 0,99598 \\
& & & 8 & 89 \\
2 day & 619,4651 & 23,66482 & 5,60889 & 0,99658 \\
& & & 0 & 8 \\
3 day & 528,9307 & 21,51465 & 3,84145 & 0,99733 \\
& & & & 84 \\
4 day & 495,1706 & 20,56573 & 1,60403 & 0,99769 \\
& & & & 53 \\
\hline
\end{tabular}

The kinetics constants of biogas production from sawdust saw in Table 3 can be seen in saw 2 teak sawdust soaked with $\mathrm{NaOH} 4 \% \mathrm{w} / \mathrm{v}$, the highest A and $\mathrm{U}$ constant values are immersion for 1 day ie $914,5903 \mathrm{ml}$ and $34,59765 \mathrm{ml} / \mathrm{gr}$ TS.day, but the lowest $\lambda$ is 4 days ie 1.60403 days

Pretreatment with $\mathrm{NaOH} 4 \% \mathrm{w} / \mathrm{v}$ for 4 days is variable that makes the fastest biogas among 4 other variables because the content of lignin and hemicellulose is $25.79 \%$ and $7.9 \%$, thus speeding up the hydrolysis process [49-51]. While in the process of hydrolysis is solved by anaerobic bacteria that release a special enzyme that serves to cut the bonds of molecular units, because the molecule is too large [52]. Rapid hydrolysis rate will decrease adaptation phase or minimum start of biogas production $(\lambda)$ [19], but immersion for 4 days does not get large $A$ and $U$ values. The highest $A$ and $U$ values obtained 1 day immersion variable. This phenomenon is caused by the 4 days of absorbing $\mathrm{NaOH}$ more than the 1 day variable. $\mathrm{Na}+$ can cause the inhibition of Aerobic Digestion process especially in methanogenesis process [21], so the process of biogas formation in variable 4 days is less than 1 day variable which less $\mathrm{NaOH}$ absorption. The formation of biogas on the 1 day variable tends to be slower because the number of lignin and hemicellulose is higher than 4 days, ie $27.34 \%$ and $8.57 \%$. High levels of lignin and hemicellulose cause more difficult process of microbial biodegradation more difficult, so the process of hydrolysis runs more slowly.

\section{Conclusion}

Pretreatment for 1 day produce the highest biogas that is $709 \mathrm{ml} / \mathrm{g} \mathrm{TS}$, but it takes a long time to produce it. The longer the pretreatment using $\mathrm{NaOH}$ the faster the formation of biogas, this is proven by pretreatment for 4 days to produce the first biogas according to kinetic calculation, which is 1.60403 days because it has low lignin and hemicellulose, that is $25.79 \%$ and $7.9 \%$. The amount of methanamine Nmethyl also increases after delignification of $\mathrm{NaOH}$ and before immersion. 


\section{References}

1. Purwanto, D, Riset Industri. V, 1, 13-20 (2011)

2. Iphegan, J, O., Evelyn, V, O., IJAIEM. 2, 6, 91-93 (2013)

3. Haryati, T., Wartazoa. 16, 3, 160-169 (2006)

4. Budiyono, Widiasa, I, N., Johari, S., Sunarso, International Journal of Basic and Applied Sciences UBAS-IJENS, 10, 1 (2010)

5. Budiyono, Widiasa, I, N., Johari, S., Sunarso, International Journal of Engineering and Technology. 1, 3, 109-116 (2009)

6. Putri, D, A, Saputro, R, R., Budiyono, Int. Journal of Renewable Energy Development, 1, 2, 61-64 (2012)

7. Frigon, J, C., Guiot, S, R., Biofuels Bioprod. 4, 447-458 (2010)

8. Juanga, J, P., Visvanathandan, C., Tränkler, J., J Waste Manage Res. 25, 30-38 (2007)

9. Karellas, S, B., Jurnal Renewable and Sustainable Energy Reviews 14, 1273-1282 (2010)

10. Shitophyta, L, M., Budiyono., Fuadi, A, M., AIP Conference Proceedings. 1699 (2015)

11. Xu, F., Shi, J., Lv, W., Yu, Z., Li, Y., Waste Management 33, 1, 26-32 (2013)

12. Quintero, M, Castro L, Ortiz C, Guzman C, Escalante, H., Bioresource Technology 108, 8-13 (2012)

13. Deublein D, Steinhauser, Deggendorf (2008)

14. Zou J, Li Y., Bioresource Technology 218, 18-26 (2016)

15. Syafrudin, Dwi Nugraha W, Hawali Abdul Matin $\mathrm{H}$, Budiyono, MATEC Web of Conferences 101 doi:10.1051/matecconf/201710102016 (2017)

16. Lin L, Yang L, Xu F, Michel F C, Li Y. Bioresource Technology 169, 439-446(2014)

17. Shi J, Xu F, Wang Z, Stiverson J A, Yu Z, Li Y., Bioresource Technology 157, 188-196(2014)

18. Zhu J, Wan C, Li Y., Bioresource Technology. 101, 19, 7523-7528(2010)

19. Taherzadeh M, Karimi K., Int J Mol Sci. 9, 9, 1621-51(2008)

20. Zheng Y, Pan Z, Zhang R., Int J Agric and BiolEng. 2, 3, 51-68(2009)

21. Zheng Y, Zhao J, Xu F, Li Y., Progress in Energy and Combustion Science. 42, 1, 35-53 (2014)

22. Yang L, Xu F, Ge X, Li Y., Renewable and Sustainable Energy Reviews. 44, 824-834 (2015)

23. MacLellan J, Chen R, Kraemer R, Zhong Y, Liu Y, Lio W., Bioresource Technology 130, 418-423 (2013)

24. Hendriks, ATWM., Zeeman, G., Bioresource Technol. 100, 1, 10-8 (2009)

25. Chen BY, Chen SW, Wang HT., Biomass Bioenergy 39, 182-91 (2012)

26. Julfana R. JKK. 2, 1, 52-57(2012)

27. Safaria, S., ISSN: 2303-1077, 2, 1, 46-51(2013)

28. Aldino, J, G., Fanandy, K., Juliastuti, S, R., Nuniek, H.,Jurnal Institut Teknologi Sepuluh Nopember (2010)
29. Laopaiboon, P., Thani, A., Leelavatcharamas, V., Laopaiboon, L., Bioresource Technology 101, 3, 1036-1043 (2009)

30. Tian, M., Liu, X., Liu, J., Zhao, Y., T. Chin. Soc. Agri.Eng. 29, 177-184 (2013)

31. Pang, Y., Liu, Y., Li, X., Wang, K., Yuan, H., Energy Fuel. 22, 4, 2761-2766 (2008)

32. Budiyono, Syaichurrozi, I., Sumardiono, S., Waste Technology. 1, 1, 1-5 (2013)

33. Wang, D., Ai, P., Liang, Y.,Tan, Z., Zhang, Y., Science Direct. 132, 47-55 (2015)

34. Lu, Y, P., Yang, B., Gregg, D., Saddler, J, N., Manfield, S, D., Applied Biochemistry and Biotechnology 98, 641-54 (2012)

35. Frigon, J, C., Guiot, S, R., Biofuels Bioprod. Bior. 4, 447-458 (2010)

36. He, Y., Pang, Y., Liu, Y., Li, X., Wang K., Energy and Fuels 22, 4, 2775-2781 (2008)

37. Bondesson, P, M., Galbe, M., Zacchi, G., Biofuels 6, 11 (2013)

38. Heiske S, Schultz-Jensen N, Leipold F, Schmidt J E., J. At. Mol. Phys. 1-7

39. Sari, F, P., Budiyono, B., Waste Technology 2, 1, 17-25 (2014)

40. Kim, S, K., Lee, Y, Y., Kim, T, H., Bioresource Technology 199, 42-48(2016)

41. Lay, M, K., Li, Y, Y., Noike, T., Journal Environment Engineering 124, 730-36 (1998)

42. Shin, J, D., Han, S, S., Eom, K, C., Sung, S., Park, S, W., Kim, H., Environtment. Eng. Res. 13, 2, 9397 (2008)

43. Budiyono, Widiasa, I, N., Johari, S., Sunarso, International Journal of Chemical and Biological Engineering 3, 1, 39-44(2010)

44. Mudhoo, A., Moorateeah, P, R., Mohee, R., World Academy of Science, Engineering and Technology 69, 805-10( 2012)

45. Patil, J, H., Malourdu, A, R., Mularidhara, P, L., Desai, M, L., Mahadeva, R, G, K., International Journal of Environmental Science and Development 3, 2 (2012)

46. Adiga, S., Ramya, R., Shankar, B, B., Patil, J, H., Geetha, C, R., International Conference on Biotechnology and Enviroment Management $2^{\text {nd }}$. 14, 73-78(2012)

47. Shankar, B, B., Jagadish, H., Patil, P, L., Muralidhara., Ramya, M, C., Ramya, R., Enviromental and Biogical Science 1 (2013)

48. Budiyono., Iqbal, S., Siswo, S., Engineering and Technology 7, 3, 2798-2805 (2014)

49. Gregg, D., Saddler, J, N, A., Applied Biochemical Biotechnology 711-27 (1996)

50. Grethlein, H, E., Biotechnology. 3, 155-60 (1985)

51. Palonen, H., Thomson, A, B., Tenkanen, M., Schmidt, A, S., Viikari, L., Applied Biochemical Biotechnology 117, 1-17(2004)

52. Drapcho, C, M., Nhuan, N, P., Walker, T, H. Biofuels Engineering Process Technology ( The McGraw-Hill Companies Inc., United States, 2008) 